\title{
FDI Attraction: Comparative Analysis of the Baltic States and Georgia
}

\author{
Tatiana Papiashvili ${ }^{1}$, Svetlana Saksonova ${ }^{2}$, Ramona Rupeika-Apoga ${ }^{3}$
}

\begin{abstract}
:
The attraction of foreign direct investment (FDI) is usually an economic policy priority due to its positive effects on economic growth because of new capital and technology, higher employment, new management practices, improvements in the quality of services, as well as innovation and lower production costs.

This paper aims to assess the investment climate in the Baltic states and Georgia and evaluate what are the appropriate FDI policy objectives and approaches there. It considers three international indices as measures of investment climate: Index of Economic Freedom, Corruption Perceptions Index, and Ease of Doing Business Index.

The results suggest that all three international indices are useful in assessing investment liberalization, promotion and facilitation. This paper argues that FDI policy needs to consider country-specific characteristics: for countries above a certain threshold FDI attraction depends mostly on macroeconomic and external factors, while other countries need to focus on specific reforms to improve investment climate.
\end{abstract}

Keywords: Foreign direct investment, Baltic states, Georgia, investment climate

JEL classification: F21, F44.

\footnotetext{
${ }^{1}$ International Black Sea University LLC, Georgia

${ }^{2}$ University of Latvia, Latvia

${ }^{3}$ University of Latvia, Latvia
} 


\section{Introduction}

Although, there is a continued debate on the relationship between foreign direct investment (FDI) and economic growth with contradicting findings ranging from positive to negative (Alfaro et al, 2010), most papers suggest a positive effect on economic growth (Doucoliagos et al, 2010; Franco and Kozovska, 2011). Significant positive effect of FDI on GDP was also observed in the Baltic countries (Tvaronavičienè and Grybaitė, 2007; Tvaronavičienė and Kalašinskaite, 2010; Saksonova, 2014).

FDI attraction is therefore considered as one of the most important policy priorities in many countries and Georgia is not an exception (IBRD, 2014; Guruli, 2013). In Georgia FDI constitutes a significant share of the country's GDP (Papiashvili and Ciloglu, 2015) and brings direct and indirect benefits such as access to new capital and technology, higher employment, new management practices, improvements in the quality of services, innovation and lower production costs (Charaia, et al., 2015).

Since 2004, when the Baltic countries jointed the European Union, and in Georgia broad based economic and political reforms have started after the Rose Revolution, there has been an increase in the interest to share the experience of Post-Soviet neighbours in transitioning towards Western style market economy. In this context, the Baltic experience can be useful for Georgia. This includes also the experience of the crises, for example, in Latvia, where the authorities did not follow the standard, recommended response to a balance-of-payments crisis (Blanchard, et al., 2013), also currency exposure risk management policies (Rupeika-Apoga and Nedovis, 2016). Moreover, Georgia is making further steps from recognizing to implementing of the Baltic states' reform experience in different areas such as education, national defence, business, etc. One specific example is the ongoing reform of the Georgian tax system. From January 2017 Georgia applies Estonian taxation model (Caucasus Business Week, 2017; ERR, 2016).

The aim of this paper is to assess the investment climate in the Baltic states and evaluate what are the appropriate FDI policy objectives and approaches for these countries. This is especially important for Georgia due to the recent massive outflow of FDI. In 2014 and 2015 Georgia was among top five economies with FDI outflows with 68 percent and 65,3 percent increase to the previous year, respectively (UNCTAD 2015, p. 65; UNCTAD, 2016, p. 57).

The research methods applied in the paper are both quantitative and qualitative analyses that include empirical literature review, statistical and econometric analysis of country data based on three international indices - Index of Economic Freedom, Corruption Perceptions Index, and Ease of Doing Business Index.

\section{Investment Climate Measures}


Investment liberalization, promotion and facilitation are the most important investment policy measures (UNCTAD, 2016, p. 90). Although they work hand in hand and have the same ultimate objective - attracting foreign investment, they are different types of activities. Generally, while investment liberalization is mostly oriented on entry policies for foreign investment, investment promotion emphasizes advantages of a country as an investment destination and is, therefore, often countryspecific and competitive in nature (UNCTAD, 2015, p.103). Facilitation as investment policy measure is about "making it easy for investors to establish or expand their investments, as well as to conduct their day-to-day business in host countries" (UNCTAD, 2016, p.117).

In this paper investment climate, will be measured based on the three types of investment policies (investment liberalization, promotion and facilitation) in the Baltic states and Georgia using three international indices, Index of Economic Freedom, Corruption Perceptions Index, and Ease of Doing Business Index as measures. These international indices were chosen to make the comparison more objective and valuable. They are assumed to be relevant measures of the investment climate in a country because (a) they are recognized internationally, (b) each index is based on a standardized set of data, (c) each is calculated using a standardized methodology, (d) many investors base their investment decisions on similar indices, (e) a sufficiently long time series is available for each of the countries.

These indices are clearly not the only determinants of FDI. Other factors include important macroeconomic variables (e.g. inflation, and current account balance), as well as broader development indicators - the level of education of the population and the development of infrastructure (Sorin, 2016). Nevertheless they are the ones that could be affected by policies relatively quickly and are therefore of crucial interest to policymakers.

\subsection{Index of Economic Freedom}

The Index of Economic Freedom, compiled by the Heritage Foundation, measures the degree to which the policies and institutions of countries are supportive of economic freedom through promoting conservative public policy. The index broadly considers lower taxes, smaller government, and fewer labour regulations to be better for the economy. A total of twelve specific components of economic freedom are grouped into four key aspects of economic environment (The Heritage Foundation, 2016):

1. Government size - this aspect includes the tax burden (both marginal tax rates and the overall burden of taxation), government spending, deficits and the level of government debt.

2. Rule of law - this aspect focuses on the security of physical and intellectual property rights, judicial effectiveness and government integrity. 
3. Regulatory efficiency - this includes business freedom measuring the extent to which regulation constrains business activities (based on the World Bank Doing Business index), labour freedom, which focuses on various aspects related to labour market flexibility and monetary freedom measuring price stability.

4. Market openness - this includes trade freedom, measuring the extent to which trade barriers affect the free flow of goods and services, investment freedom (focused on the free flow of capital) and financial freedom.

Table 1. Index of Economic Freedom in the Baltic countries and Georgia (20052015)

\begin{tabular}{|l|l|l|l|l|l|l|l|l|l|l|l|l|}
\hline & $\begin{array}{l}200 \\
5\end{array}$ & $\begin{array}{l}200 \\
6\end{array}$ & $\begin{array}{l}200 \\
7\end{array}$ & $\begin{array}{l}200 \\
8\end{array}$ & $\begin{array}{l}200 \\
9\end{array}$ & $\begin{array}{l}201 \\
0\end{array}$ & $\begin{array}{l}201 \\
1\end{array}$ & $\begin{array}{l}201 \\
2\end{array}$ & $\begin{array}{l}201 \\
3\end{array}$ & $\begin{array}{l}201 \\
4\end{array}$ & 201 & 5 \\
5 & Av. \\
\hline Estonia & 75.2 & 74.9 & 78.0 & 77.9 & 76.4 & 74.7 & 75.2 & 73.2 & 75.3 & 75.9 & 76.8 & 75.8 \\
\hline Latvia & 66.3 & 66.9 & 67.9 & 68.3 & 66.6 & 66.2 & 65.8 & 65.2 & 66.5 & 68.7 & 69.7 & 67.1 \\
\hline Lithuania & 70.5 & 71.8 & 71.5 & 70.9 & 70.0 & 70.3 & 71.3 & 71.5 & 72.1 & 73.0 & 74.7 & 71.6 \\
\hline $\begin{array}{l}\text { Average } \\
\text { in the } \\
\text { group } \\
\text { (Baltics) }\end{array}$ & 70.7 & 71.2 & 72.5 & 72.3 & 71.0 & 70.4 & 70.8 & 70.0 & 71.3 & 72.5 & 73.7 & 71.5 \\
\hline Georgia & 57.1 & 64.5 & 67.9 & 68.3 & 69.8 & 70.4 & 70.4 & 69.4 & 72.2 & 72.6 & 73.0 & 68.7 \\
\hline
\end{tabular}

Source: (The Heritage Foundation, 2017), Authors' calculations. Note: A higher value denotes greater economic freedom with 100 being the maximum score.

Figure 1. The Index of Economic Freedom (Baltic average and Georgia, 20052015.

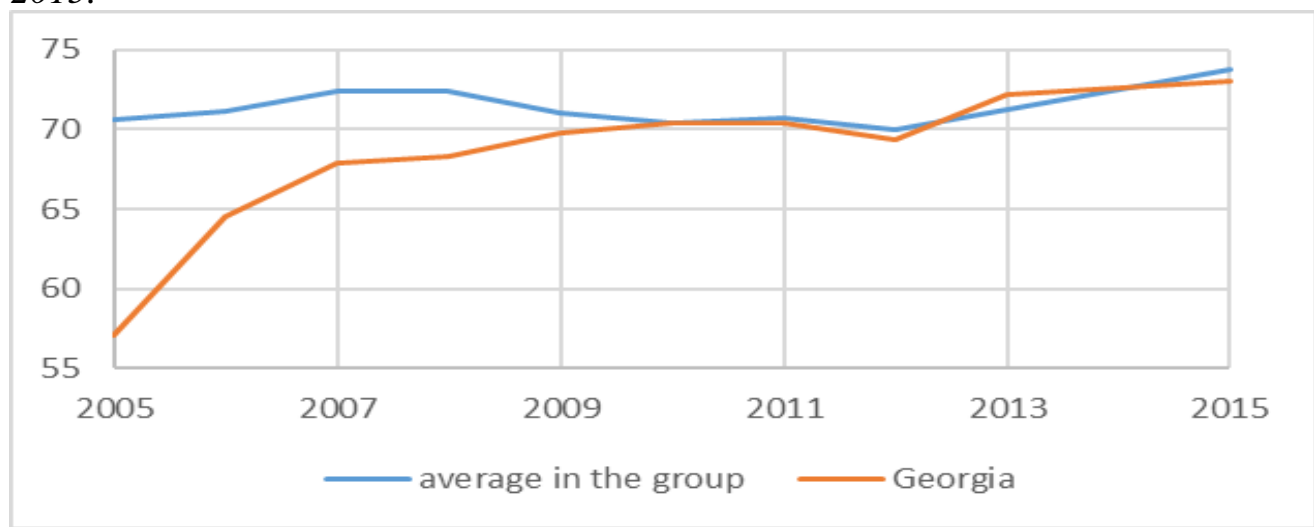

Source: (The Heritage Foundation, 2017), Authors' calculations.

As Table 1 and Figure 1 indicate all three Baltic states and Georgia have relatively high levels of economic freedom. In the period observed Estonia is on average the highest ranked country of the four and Latvia is the lowest ranked Baltic country. It should be stressed that the economic freedom indicator appears to be relatively constant for all three Baltic countries. 
On the other hand, since 2004 Georgia has demonstrated significant improvement of the economic freedom indicator. In 2016 Georgia was ranked $23^{\text {rd }}$ among 178 countries, and $12^{\text {th }}$ among 45 European states. Georgia fell under the category of "mostly free", which also included the Baltic states, the United States and most of the developed countries. Georgia is ahead of all four of its neighbors and the majority of Post-Soviet countries in almost all measures underlying the index, and is ahead of all the Eastern European countries with its overall result (The Heritage Foundation, 2016). Despite the generally positive results, Georgia has relatively low scores in three components of the Index of Economic Freedom: property rights (40 out of a 100), freedom from corruption (52 out of a 100), financial freedom (60 out of a 100).

Economic freedom has increased in Latvia in recent years, because the government has made contract enforcement and property transfers easier by restructuring its courts and introducing other new procedures. Although judicial independence is generally respected and property rights are protected, the public distrusts the judicial system, which it views as inefficient, politicized, and corrupt (making judicial effectiveness score a low of 59.7). There are significant concerns regarding accountability for corruption. Poor governance and inefficiency in state-owned enterprises, limited financial freedom remain problematic resulting in low government spending and financial freedom scores (57.4 and 60 respectively) (The Heritage Foundation, 2017).

For the purposes of this paper, one of the most relevant components of the index is investment freedom (underlying variable for market openness measure) that is a direct measure of investment environment in a country for both domestic and foreign investors. Figure 2 shows the dynamic of investment freedom in the Baltic countries and Georgia after the global financial crisis of 2008-09. One can see that the Baltic states have about stable position (scores) with insignificant improvement in Latvia while Georgia greatly improved its scores - from 70 to 80. The leading country in the group is Estonia.

Figure 2. Investment Freedom Index scores in the Baltic countries and Georgia, 2010-2016. 


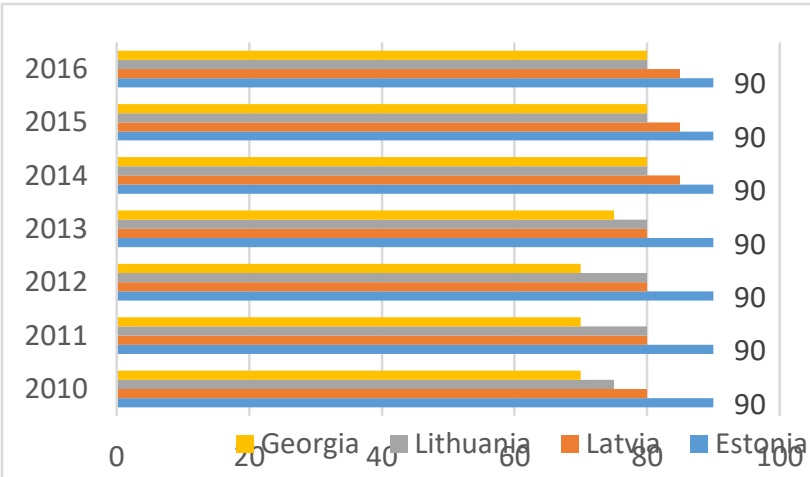

Source: (The Heritage Foundation, 2017).

\subsection{Corruption Perceptions Index}

By definition, corruption is hard to measure. One of the most authoritative attempts is the Corruption Perceptions Index (CPI), compiled by Transparency International which is focused on public perceptions of corruption in a given country. CPI is a composite index combining surveys and assessments of corruption compiled by a variety of institutions.

Table 2 shows the evolution of corruption perceptions in observed countries. The highest-ranking country is Estonia, with the average score of 6.6 in 2005-2015. Among the Baltic countries Latvia has the lowest average score (Transparency International, 2016). In the observed decade, the average score of the perceived levels of public sector corruption in Georgia was significantly lower (4.1) compared with the average score of the three Baltic states (5.5) suggesting that, despite Georgian government anticorruption policy, corruption is still a problem for the country. In 2016 Estonia was ranked $22^{\text {nd }}$ out of 176 countries, while Latvia and Georgia had the lowest ranking $-44^{\text {th }}(5.7$ score $)$ and Lithuania was ranked $38^{\text {th }}$ with 5.9 score.

Table 2. Corruption Perception Index in the Baltic countries and Georgia (2005-15)

\begin{tabular}{|l|l|l|l|l|l|l|l|l|l|l|l|l|}
\hline & $\begin{array}{l}\mathbf{2 0 0} \\
\mathbf{5}\end{array}$ & $\begin{array}{l}\mathbf{2 0 0} \\
\mathbf{6}\end{array}$ & $\begin{array}{l}\mathbf{2 0 0} \\
\mathbf{7}\end{array}$ & $\begin{array}{l}\mathbf{2 0 0} \\
\mathbf{8}\end{array}$ & $\begin{array}{l}\mathbf{2 0 0} \\
\mathbf{9}\end{array}$ & $\begin{array}{l}\mathbf{2 0 1} \\
\mathbf{0}\end{array}$ & $\mathbf{2 0 1}$ & $\mathbf{2 0 1}$ & $\mathbf{2 0 1}$ & $\mathbf{2 0 1}$ & $\mathbf{2 0 1}$ & $\mathbf{A v}$ \\
$\mathbf{5}$ & $\mathbf{5}$ & $\mathbf{5}$ \\
\hline Estonia & 6.4 & 6.7 & 6.5 & 6.6 & 6.6 & 6.5 & 6.4 & 6.4 & 6.8 & 6.9 & 7.0 & 6.6 \\
\hline Latvia & 4.2 & 4.7 & 4.8 & 5.0 & 4.5 & 4.3 & 4.2 & 4.9 & 5.3 & 5.5 & 5.5 & 4.8 \\
\hline $\begin{array}{l}\text { Lithuani } \\
\text { a }\end{array}$ & 4.8 & 4.8 & 4.8 & 4.6 & 4.9 & 5.0 & 4.8 & 5.4 & 5.7 & 5.8 & 6.1 & 5.2 \\
\hline $\begin{array}{l}\text { Average } \\
\text { in the } \\
\text { group } \\
\text { (Baltics) }\end{array}$ & 5.1 & 5.4 & 5.3 & 5.4 & 5.3 & 5.2 & 5.1 & 5.6 & 5.9 & 6.1 & 6.2 & 5.5 \\
\hline Georgia & 2.0 & 2.3 & 3.4 & 3.9 & 4.1 & 3.8 & 4.1 & 5.2 & 5.2 & 4.9 & 5.2 & 4.1 \\
\hline
\end{tabular}


Source: (Transparency International, 2016), Authors' calculations.

Notes: A higher value denotes greater freedom from corruption (cleaner governance) with 10 being the maximum score. In 2012 the scale was adjusted from 0 to a 100, however, results are given here on a comparable basis.

\subsection{Ease of Doing Business Index}

The World Bank Doing Business Index evaluates countries' business environment and ranks countries according to their score on an index measuring the overall soundness of the business environment, investigating the regulations that enhance business activity and those that constrain it. Specifically, the index assesses regulations in 189 economies (2016) or 190 economies (2017), and ranks and compares economies with one another in ten areas of business regulation. The ten areas include: starting a business, dealing with construction permits, getting electricity, registering property, getting credit, protecting investors, paying taxes, trading across borders, enforcing contracts, and resolving insolvency (World Bank, 2017a). When compared across years, the distance to frontier score shows how much the regulatory environment for local entrepreneurs in an economy has changed over time in absolute terms, while the ease of doing business ranking can show only how much the regulatory environment has changed relative to that in other economies (World Bank, 2017b, p.164). In other words, the Ease of Doing Business Index averages the country's percentile rankings on ten topics which, in turn, are the simple average of the percentile rankings on its component indicators.

The Doing Business index has some limitations and constraints. Specifically, several commentators have questioned the relationship between the ranking in the Doing Business Index and the underlying business environment (Høyland, et al., 2014; Cappiello, 2014). Moreover, because the coverage of the World Bank Doing Business report has been constantly expanded in terms of increasing both the number of topics and the number of countries, it is not possible to present a comparable time series for the entire period.

The paper uses both measures - the Ease of Doing Business Index and Ranking, because using the index provides the basis for qualitative research while ranking is a widely known indicator and it is very popular among policymakers and politicians. Figure 3 shows the evolution of the ease of doing business rankings from 2006 to 2016 for Georgia and the Baltic states.

Figure 3 shows that Georgia demonstrated impressive improvements in the Ease of Doing Business Rankings. Georgia went from being 100th in 2006 (corresponding to unattractive business regulation) to a record high of 8th place in 2014 (among the economies with the most business-friendly regulation). As for the Baltic states, the business regulation and the Ease of Doing Business rankings are quite stable there 
reflecting common European Union standards that have been successfully adopted in these countries.

In 2016 Georgia received the highest score on the ease of starting a business (96.13 out of 100 ranked sixth in the world; by contrast, the United States was ranked at $49^{\text {th }}$ place) and ease of registering property (ranked third in the world behind only New Zealand and Lithuania). The country has the worst result in resolving insolvency, with a score of 40 (out of 100) and performed relatively poorly in trading across the border (86.2 out of 100) (World Bank, 2016). In 2017 Georgia was found to be among the top global reformers for implementing business friendly reforms (World Bank, 2017c).

Figure 3. The Ease of Doing Business Rankings of the Baltic States and Georgia, 2006-2016

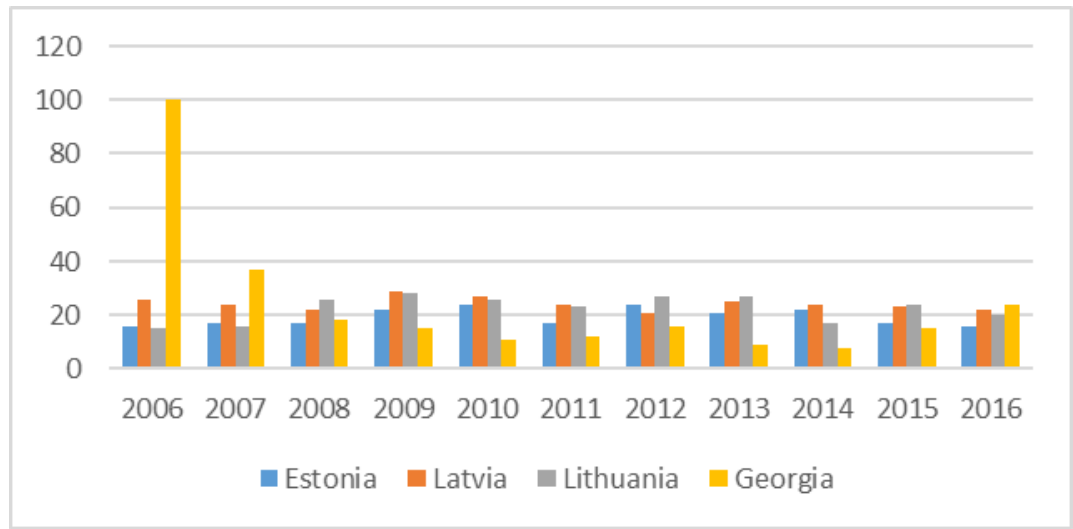

Source: (World Bank, 2016).

\section{Empirical Analysis}

This paper studies the relationship of the foreign direct investment with each of the indicators outlined above. One of the key questions for setting up the empirical framework is whether the level or the changes of the indicators should be considered together with the level or changes in FDI. Given the relatively limited sample size this paper focuses on the levels.

Another important question is whether one should consider foreign direct investment as a ratio to GDP as a dependent variable. This is done in some papers in order to abstract from the effects of the business cycle (Saksonova, 2014). However, this paper takes the second approach - examining the relationships between the indices and the level of FDI. This is because, improvements in the measures of investment attractiveness may have positive effects on GDP as well as on FDI. For example, improvements in the Doing Business ranking may increase domestic as well as foreign investment. In that case, the effects on the ratio of FDI to GDP would be ambiguous. 
The time sample used for the empirical analysis is between 2005 and 2015. The 2016 outturns are still subject to revisions and are therefore not included in the analysis. Figure 4 presents simple scatter plots of foreign direct investment together with an estimated linear trend and the coefficient of determination (R-squared) for the Index of Economic Freedom. The figure shows that:

- there is a definite positive relationship between Economic Freedom Index and the amount of foreign direct investment; higher levels of the index are associated with higher levels of foreign direct investment in each observed country;

- however, the value of R-squared significantly varies by countries; R-squared is very low in the Baltic states while in Georgia it is about ten times higher but is still low;

- in the Baltic countries components of Economic Freedom Index do not affect FDI as intensively as in Georgia.

These results could be interpreted to suggest that the Baltic states have achieved a sufficiently high level of all components of the Economic Freedom Index so that time variation around this already high level has a relatively small effect on FDI and other, for example, macroeconomic factors, which are not controlled for in this regression matter more. Moreover, one should remember that in any country not only economic factors affect FDI but political priorities may become influential. Obviously the indices used do not cover other certain economic and political factors which are beyond the national governments' control such as the situation in the global economy or even in the region.

On the other hand, one can see that for Georgia, which started with relatively lower values of index of economic freedom and increase in the index due to policy reforms has helped generate FDI. The results suggest that 28 percent of the time variation in the level of FDI can be explained by the dynamics of the economic freedom index. Other factors that could be driving investment would include the development of infrastructure (including cross-border, regional connections), economic growth in neighboring countries, etc. 
Figure 4. Relationship between Index of Economic Freedom and FDI (the Baltic states and Georgia, 2005-2015)

a. Estonia

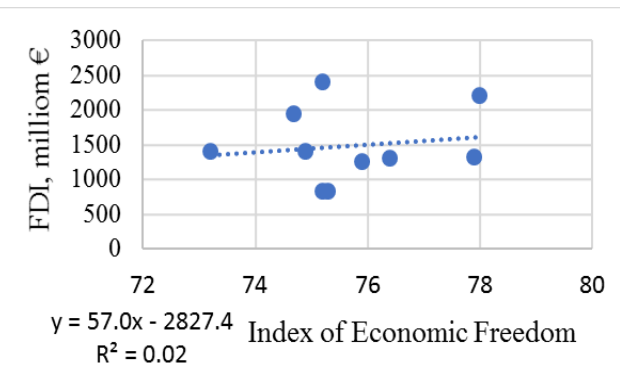

\section{b. Lithuania}

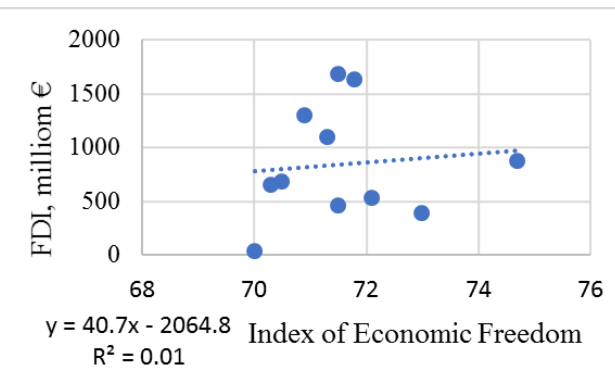

Source: Authors' calculations.
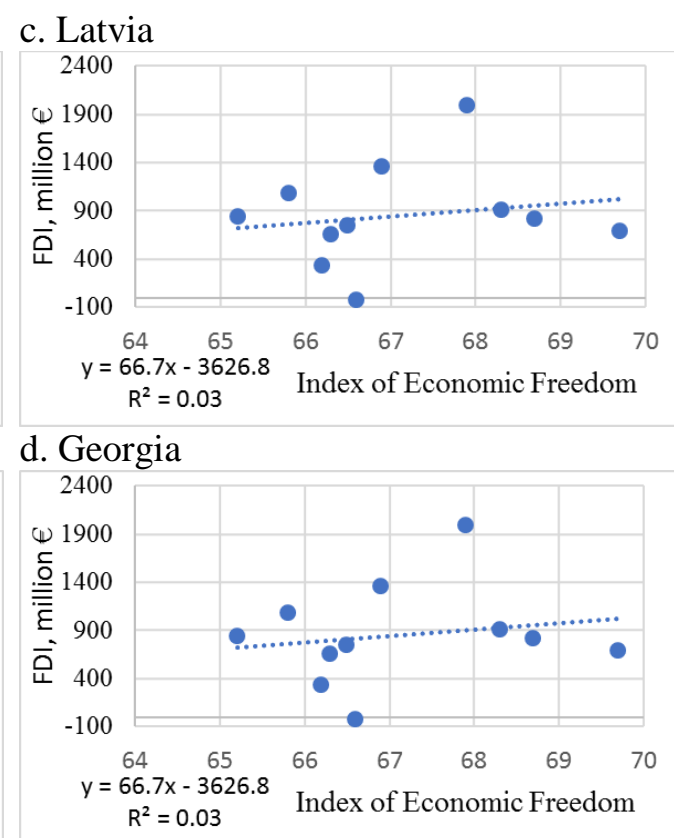

The results should be interpreted in context of obvious statistical limits, first and foremost, the short available time period and the resulting small sample size. Small sample size is also what makes a multivariate regression less tractable. Panel regressions have been used in the literature to address these shortcomings, however, this approach is not pursued in this paper because it focuses on the specific countries seeking to contrast their divergent experiences.

The same linear regression method can be easily applied to the other variables considered in this paper. Table 3 presents the results of econometric analysis of the relationships between Corruption Perception Index and Ease of Doing Business Index, on one hand, and FDI, on another, in each country. The findings of econometric analysis are mixed and may be summarized as follows:

\section{A. Corruption Perception Index}

- For all observed countries, R-squared and correlation coefficient (r) have very low value that indicates that the evidence for linear correlation is weak to none. As discussed earlier, this does not mean that these factors are not important or do not measure investment environment well. More likely this means that the relationship may be more complicated, for example, nonlinear and that other factors could be important.

- In Estonia and Lithuania correlation coefficient $(r)$ indicates negative correlation which is counterintuitive. This is most likely due to the omitted variables bias. 
For example, if the negative impact of the global financial crisis on FDI is stronger than the positive impact of improved corruption perceptions, the analysis could falsely indicate that improved corruption perceptions have a negative effect on FDI since both developments occurred during the sample period considered.

Table 3. Relationships between Corruption Perception Index and Ease of Doing Business Index and FDI (2005-2015)

\begin{tabular}{|l|l|l|l|l|l|l|}
\hline \multirow{2}{*}{ Country } & \multicolumn{2}{|l|}{ Corruption Perception Index } & \multicolumn{2}{l|}{ Ease of Doing Business Index } \\
\cline { 2 - 7 } & $\begin{array}{l}\text { Regression } \\
\text { equation }(\mathbf{y})\end{array}$ & $\mathbf{R}^{\mathbf{2}}$ & $\begin{array}{l}\text { Correlation } \\
\text { coefficient } \\
(\boldsymbol{r})\end{array}$ & $\begin{array}{l}\text { Regression } \\
\text { equation }(\mathbf{y})\end{array}$ & $\mathbf{R}^{\mathbf{2}}$ & $\begin{array}{l}\text { Correlation } \\
\text { coefficient } \\
(\boldsymbol{r})\end{array}$ \\
\hline Estonia & $\begin{array}{l}\mathrm{y}=-1303 \mathrm{x}+ \\
10057\end{array}$ & 0.18 & -0.43 & $\begin{array}{l}\mathrm{y}=7.42 \mathrm{x}+ \\
1232.9\end{array}$ & 0.00 & 0.05 \\
\hline Latvia & $\begin{array}{l}\mathrm{y}=117.02 \mathrm{x} \\
+288.33\end{array}$ & 0.01 & 0.11 & $\begin{array}{l}\mathrm{y}=-100.81 \mathrm{x} \\
+3341.3\end{array}$ & 0.19 & -0.44 \\
\hline Lithuania & $\begin{array}{l}\mathrm{y}=-326.07 \mathrm{x} \\
+2518.9\end{array}$ & 0.11 & -0.33 & $\begin{array}{l}\mathrm{y}=-68.28 \mathrm{x}+ \\
2427.3\end{array}$ & 0.39 & -0.62 \\
\hline Georgia & $\begin{array}{l}\mathrm{y}=172.48 \mathrm{x} \\
+449.62\end{array}$ & 0.15 & 0.38 & $\begin{array}{l}\mathrm{y}=1.78 \mathrm{x}+ \\
1210.7\end{array}$ & 0.01 & 0.11 \\
\hline
\end{tabular}

Source: Authors' calculations.

\section{B. The Ease of Doing Business Index}

- As in the previous cases, R-squared and correlation coefficients (r) are very low.

- In Latvia and Lithuania, the correlation coefficient (r) indicates negative correlation between these two variables contradicting the predictions of economic theory. The reasons for this are similar to the case of the corruption perceptions index - other developments over the sample period that likely had a more significant effect on FDI. For Latvia and Lithuania, one additional example could be the developments in the banking sector, which is dominated by Scandinavian groups. When they choose to withdraw profits or capital from their Scandinavian subsidiaries, this would register as foreign direct investment outflow, although it is not necessarily related to the deterioration in the economic environment.

\section{Conclusions and recommendations}

Despite the statistical limitations of the empirical anlaysis, the findings are quite meaningful. All three international indices used in the research (Index of Economic Freedom, Corruption Perceptions Index, and Ease of Doing Business Index) are relevant measures of investment climate in observed countries or, to be more precise, the indices are useful in assessing investment liberalization, promotion and facilitation. However, the research shows mixed results that is the intensity of correlation varies by countries. This discrepancy of relationships between components of the indices and FDI suggests that one should be careful with radical policy experiments (in Georgia, for instance, such as radical deregulation reforms in 
Saakashvili's period or current tax reform to apply Estonia's currency board and 0 percent corporate tax), which may have significant short-term costs and whose longterm impact may be uncertain.

To work out FDI attraction policy, national policymakers should not only adopt unified, common goals and approaches but also consider country-specific characteristics. At least for countries that have achieved sustainability and sufficient value of most components of indices (in this case, Estonia), further FDI attraction depends mostly on other fundamental factors (including macroeconomic and/or external political and economic forces) while for Latvia, some of the main obstacles for the development of favorable investment climate are judicial ineffectiveness, corruption, limited financial freedom, poor governance and inefficiency in stateowned enterprises. Finally, in Georgia, there is scope for improvement of country's investment climate through further reforms on property rights, freedom from corruption and financial freedom.

More data, in particular, micro-level data (about individual firms and investments) is needed to analyze the determinants of FDI in the countries considered with greater precision. By outlining key stylized facts of the evolution of investment environment in the Baltics and Georgia, this paper can make a step towards this important research agenda.

\section{References:}

Alfaro, L., Chanda, A., Kalemli-Ozcan, S., Sayek, S. 2010. Does foreign direct investment promote growth? Exploring the role of financial markets on linkages. Journal of Development Economics, 91(2).

Blanchard, O.,Griffiths, M., Gruss, B. 2011. Bust, Recovery: Forensics of the Latvia Crisis. https://www.brookings.edu/wpcontent/uploads/2016/07/2013b blanchard latvia crisis.pdf.

Cappiello, A. 2014. World Bank Doing Business project and the statistical methods based on ranks: The paradox of the time indicator. Rivista Italiana di Economia Demografia e Statistica, Volume LXVIII n.1 Gennaio-Marzo, 79-86.

Caucasus Business Week. 2017. Georgia Welcomes Estonian Taxation Model. http://cbw.ge/economy/georgia-welcomes-estonian-taxation-model/.

Charaia, V., Anguridze, O., Doghonadze, I. 2015. Georgia's foreign direct investments (FDI) - fundamental analysis. http://cbw.ge/economy/georgias-foreign-directinvestments-fdi-fundamental-analysis/.

IBRD, 2014. Country Partnership Strategy for Georgia. 2014 - 2017. http://documents.worldbank.org/curated/en/249271468274498717/pdf/852510CAS0 P144080Box385177B00OUO090.pdf. .

Doucoliagos, H., Iamsiraroj, S., Ulubasoglu, M.A. 2010. Foreign Direct Investment and Economic Growth: A real relationship or wishful thinking? Deakin University Faculty of Business and Law School Working Paper 14.

ERR. 2016. Georgia to follow Estonia's example and only tax distributed profit. http://news.err.ee/118174/georgia-to-follow-estonia-s-example-and-only-taxdistributed-profit. 
Franco, C., Kozovska, K. 2011 In E. Rugraff, M.W. Hansen eds., Multinational corporations and local firms in emerging economies. Amsterdam University Press, Ch. 5

Guruli, I.2013. Understanding Georgia's Foreign Direct Investment Trends, http://dfwatch.net/understanding-georgias-foreign-direct-investment-trends-8103019920.

The Heritage Foundation 2016. 2016 Index of Economic Freedom: Promoting Economic Opportunity and Prosperity. http://www.heritage.org/index/pdf/2016/book/index_2016.pdf.

The Heritage Foundation 2017. 2017 Index of Economic Freedom. http://www.heritage.org/index/country/latvia.

Høyland. B., Moene, K., Willumsen, F. 2014. Be careful when Doing Business. https://web.archive.org/web/20110726171432/http://ifiwatchnet.org/sites/ifiwatchne t.org/files/Doing\%20Business_ESOPanalysis.pdf.

Papiashvili, T. and Ciloglu, I., 2015. SMEs and country's growth strategy: Evidence from Georgia. Journal of Business (IBSUJB), 4(1), 25-30

Rupeika-Apoga, R. and Nedovis, R. 2016. The Foreign Exchange Exposure of Domestic Companies in Eurozone: Case of the Baltic States. European Research Studies Journal, 19(1), 165-178.

Saksonova, S. 2014. Foreign direct investment attraction in the Baltic states. Verslas: Teorija ir praktika / Business: Theory and Practice, 15(2), 114-120.

Sorin, G.A. 2016. Foreign Direct Investment Flows and IMF Lending Programs. New Empirical Evidence from CESEE Countries. Scientific Annals of Economics and Business, 63(3).

Transparency International. 2016. Corruptions Perceptions Index 2016. http://www.transparency.org/news/feature/corruption_perceptions_index_2016.

Tvaronavičienè, M., Grybaitè, V. 2007. Impact of FDI on Lithuanian Economy: Insight into Development of Main Economic Activities. Journal of Business Economics and Management, 3(4), 285-290.

Tvaronavičienė, M., Kalašinskaite, K. 2010. Whether globalization in form of FDI enhances national wealth: empirical evidence from Lithuania. Journal of Business Economics and Management, 11(1), 5-19.

UNCTAD. 2015. World Investment Report: Reforming international investment governance. http://unctad.org/en/PublicationsLibrary/wir2015 en.pdf.

UNCTAD. 2016. World Investment Report: Investor Nationality: Policy Challenges. http://unctad.org/en/PublicationsLibrary/wir2016_en.pdf.

World Bank, 2016. Doing Business 2016. Measuring Regulatory Quality and Efficiency. http://espanol.doingbusiness.org/ /media/WBG/DoingBusiness/Documents/AnnualReports/English/DB16-Full-Report.pdf.

World Bank, 2017a. Doing Business 2017. http://www.doingbusiness.org/ /media/WBG/DoingBusiness/Documents/AnnualReports/English/DB17-Chapters/DB17-DTF-and-DBRankings.pdf.

World Bank, 2017b. Distance to Frontier and Ease of Doing Business Ranking, http://www.doingbusiness.org/data/distance-to-frontier.

World Bank, 2017c. Doing Business 2017. Equal Opportunity for All. World Bank Group 2017. http://www.doingbusiness.org/ /media/WBG/DoingBusiness/Documents/AnnualReports/English/DB17-Report.pdf. 